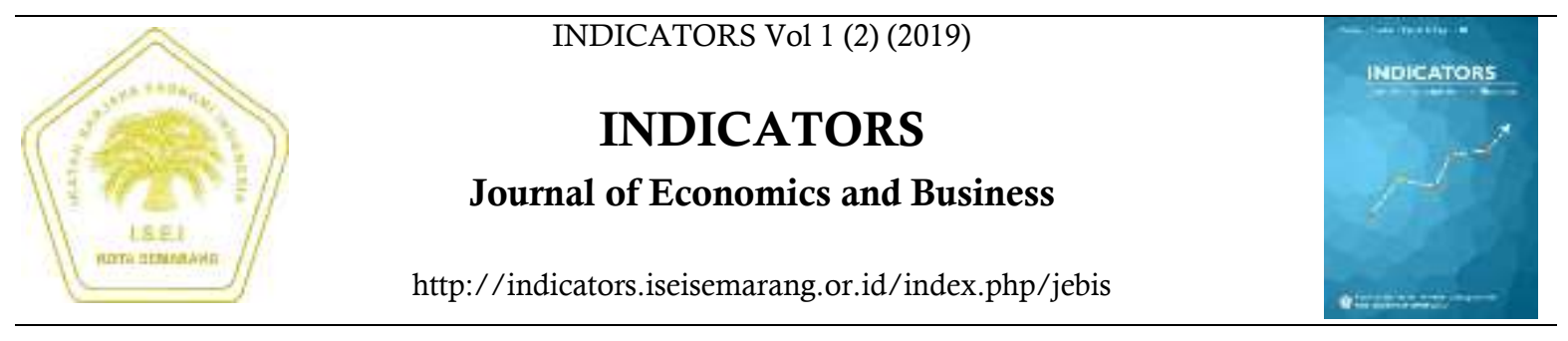

\title{
KAUSALITAS KONSUMSI ENERGI HYDROELECTRICITY, EMISI KARBON DIOKSIDA TERHADAP PERTUMBUHAN EKONOMI DI INDONESIA
}

\author{
Nani Dwi I.S., Fika Rahmadani, Dewi Pardian I.P. ${ }^{\bowtie}$, Devana Shofi Yudatama \\ Jurusan Ekonomi Pembangunan, Fakultas Ekonomi, Universitas Negeri Semarang
}

\begin{tabular}{|c|c|}
\hline Info Artikel & ABSTRAK \\
\hline $\begin{array}{l}\text { Sejarah Artikel: } \\
\text { Diterima Mei } 2019 \\
\text { Disetujui Agustus } 2019 \\
\text { Dipublikasikan } \\
\text { November } 2019\end{array}$ & $\begin{array}{l}\text { Penitian ini bertujuan untuk mengetahui kausalitas konsumsi energi hydroelectricity dan emisi CO2 } \\
\text { terhadap perekonomian di Indonesia pada periode 1981-2017. Data penelitian ini berasal dari World } \\
\text { Bank dan IEA tahun 2017. Metode yang digunakan yaitu Granger causality dan VAR untuk } \\
\text { mendapatkan hasil kausalitas. Hasil uji kausalitas menunjukkan bahwa ada kausalitas satu arah } \\
\text { Konsumsi Energi Hydroelectricity CO2 dan Gross Domestic Bruto, namun untuk Konsumsi Energi } \\
\text { Hydroelectricity dan CO2 menunjukan kausalitas dua arah di Indonesia. }\end{array}$ \\
\hline
\end{tabular}

Keywords:

emisi CO2, konsumsi energi

hydroelectricity, gross

domestic product

\footnotetext{
$\triangle$ Alamat korespondensi:

Fakultas Ekonomi Universitas Negeri Semarang Gedung L1,

Lantai 1, Kampus Sekaran Gunungpati Semarang

E-mail: (dewiintan19@students.unnes.ac.id)
} 


\section{PENDAHULUAN}

Energi merupakan hal yang sangat penting dalam berlangsungnya perekonomian bangsa. Khususnya bahan bakar fosil telah menjadi komponen yang paling banyak yang digunakan untuk kegiatan ekonomi di seluruh dunia. Namun, adanya perluasan yang memakan energi di negara-negara maju dan berkembang yang membuat keprihatinan utama yakni menipisnya sumber daya energi terutama minyak bumi dan juga masalah pemanasan global yang disebabkan oleh meningkatnya emisi gas rumah kaca seperti karbon dioksida $\left(\mathrm{Co}_{2}\right)$. Tantangan energi yang bersifat global ini mengharuskan sumber daya energi terbarukan dikelola dan dipergunakan dengan tepat. Energi terbarukan umumnya didefinisikan sebagai energi yang dihasilkan dari matahari, angin, panas bumi, air, dan biomassa. Berlawanan energi konvensional, energi terbarukan itu aman, bersih, dan tidak pernah habis. Oleh karena itu, energi terbarukan ini berkembang cepat di seluruh dunia dan di prediksi bisa menggeser energi konvensional dalam keseluruhan energi. Seperti contoh, di China pembangkit tenaga angin meningkat lebih dari pembangkit dari batubara.

Energi terbarukan dengan cepat memperkuat perannya dalam pasokan energi di seluruh dunia. Artinya, investasi dalam energi terbarukan semakin cepat berkembang di banyak negara maju dan negara berkembang. Menurut REN21, ASEAN menyumbang rata-rata 45.7\% dalam menggunakan energi terbarukan pada 2019, Filipina berkontribusi dalam mengkonsumsi energi terbarukan sebesar $47.5 \%$ dan Indonesia sebeasar $47 \%$ terutama pada konsumsi hyropower dan bio energi.

Munculnya hydroelectricity sebagai energi alternatif yang ramah lingkungan dapat membantu mengurangi kelangkaan energi dan tentunya mengurangi emisi $\mathrm{CO} 2$. Hydroelectricity atau tenaga air adalah energi yang dihasilkan dari air yang mengalir. Pembangkit energi yang memanfaatkan air dengan cara membendung aliran air, seperti di sungai dan bendungan. Hydroelectricity bisa dimanfaatkan untuk menghasilkan energi listrik yang bisa digunakan baik untuk kebutuhan rumah tangga maupun industri. Hydroelectricity memiliki beberapa manfaat yaitu lebih hemat, lebih bersih, terbarukan, dan ramah lingkungan.

Semakin tinggi pendapatan suatu negara, maka negara tersebut akan lebih melek akan kondisi lingkungannya. Negara dengan pendapatan tinggi akan memikirkan kondisi lingkungan nya dan kualitas udaranya. Sehingga negara tersebut akan memilih menggunakan energi terbarukan dan melakukan pembangunan berkelanjutan. Negara-negara yang sudah menerapkan hydroelectricity yaitu negara ASEAN-4 yaitu Indonesia, Malaysia, Thailand, Filipina serta 3 Negara High income yaitu Amerika Serikat, Inggris, dan Jepang.

Indonesia merupakan negara berkembang yang memiliki tingkat pertumbuhan ekonomi menengah. Dalam 11 tahun dari tahun 20082017 memiliki pertumbuhan ekonomi yang cenderung meningkat pada setiap tahunnya. Sedangkan Negara High Income, dari namanya sajasudah jelas yaitu memiliki pendapatan yang tinggi. Tentunya memiliki tingkat pertumbuhan yang tinggi pula. Negara High Income merupakan negara yang sudah maju dan memiliki perekonomian yang sudah sangat bagus. Infrastruktur yang bagus dan fasilitas yang sudah memadai. Tentunya mereka memilih energi terbarukan untuk diterapkan pada negaranya. Supaya negaranya dapat ramah lingkungan dan memiliki kualitas limgkungan yang baik. Kondisi lingkungan juga harus diperhatikan, tidak hanya pada perekonomiannya saja. Negara-negara di atas dapat dikatakan memiliki perekonomian yang sudah baik sehingga kondisi dan kualitas lingkungan pun mulai dilirik dan diperbaiki. Dengan menerapkan energi hydroelectricity di negara nya masing-masing dapat menekan emisi $\mathrm{CO} 2$.

Dalam perjanjian Kyoto Protocol to the United Nations Framework Convention on Climate Change (Protokol Kyoto mengenai Konvensi Rangka Kerja PBB tentang Perubahan Iklim) menyatakan bahwa Negara-negara yang meratifikasi protokol ini berkomitmen untuk mengurangi emisi/pengeluaran karbon dioksida dan lima gas rumah kaca lainnya, atau 
bekerja sama dalam perdagangan emisi jika mereka menjaga jumlah atau menambah emisi gas-gas tersebut, yang telah dikaitkan dengan pemanasan global. Dengan menekan emisi CO2 dapat mengurangi pemanasan global. Energi terbarukan berperan penting dalam target pengurangan 50\% CO2 global pada tahun 2050 jika rata-rata jangka panjang kenaikan suhu global dibatasi antara 2 dan 2.41C. Selain keberhasilannya dalam memerangi pemanasan global, energi terbarukan cenderung mengurangi ketergantungan pada energi bahan bakar fosil yang diimpor dan meningkatkan pasokan.Barubaru ini, korelasi antara pertumbuhan ekonomi dan konsumsi energi terbarukan telah menjadi bidang penelitian substansial. Khususnya, memeriksa signifikansi arah kausalitas antara kedua variabel sangat bermanfaat, karena dapat memberikan wawasan berharga bagi pembuat kebijakan.

\section{KAJIAN PUSTAKA}

Teori yang menghubungkan degradasi lingkungan dengan tingkat pendapatan per kapita disebut sebagai Environmental Kuznets Curve (EKC). Hipotesis EKC menyatakan bahwa ketika pendapatan suatu daerah masih rendah, perhatian daerah tersebut akan tertuju pada cara meningkatkan pendapatan dengan mengesampingkan permasalahan kualitas lingkungan. Ketika pendapatan suatu daerah terus bertumbuh seiring pembangunan ekonomi, produksi manufaktur akan menyumbang sejumlah besar produk domestik regional bruto dan diiringi dengan kenaikan tingkat polusi (Nuriah Alfisyahri, Syafruddin KArimi, 2020).

Menurut Kuznets (dalam Zakiah Husna \& Idris2019) pertumbuhan ekonomi merupakan kenaikan kemampuan suatu negara dalam jangka panjang untuk memberikan berbagai jenis barang ekonomi rakyatnya. Kemampuan tumbuh sesuai dengan kemajuan teknologi, penyesuaian kelembagaan dan perlunya ideologi. Definisi ini memiliki 3 (tiga) komponen, pertama pertumbuhan ekonomi suatu bangsa terlihat dari meningkat secara terusmenerus sehingga menjadi persediaan barang. Kedua, teknologi canggih merupakan faktor dalam pertumbuhan ekonomi memastikan pertumbuhan tingkat kemampuan dalam penyampaian berbagai banyak hal untuk rakyat. Ketiga, penggunaan teknologi secara luas dan efisien perlu penyesuaian dalam kelembagaan dan ideologi sehingga inovasi yang dihasilkan oleh manusia sains dapat digunakan dengan tepat.

\section{Konsumsi energi tenaga air dan pertumbuhan ekonomi}

Abakah (1993) meneliti hubungan antara tiga sumber konsumsi energi yang berbeda, yaitu : arang, minyak bumi, dan pembangkit listrik tenaga air serta pertumbuhan ekonomi di Ghana selama periode 1976-1990. Penulis menemukan bahwa konsumsi listrik tenaga air dan minyak bumi memiliki dampak positif pada pertumbuhan ekonomi di Ghana dalam jangka pendek dan panjang, sedangkan konsumsi arang berhubungan negatif dengan pertumbuhan ekonomi.

Selanjutnya Okafor (2012), meneliti hubungan kausal antara konsumsi energi terpilah, antara lain : batubara, hidro, dan minyak serta pertumbuhan ekonomi di Nigeria dan Afrika Selatan selama kurun waktu 19702010. Mereka menemukan hubungan kausal dua arah antara konsumsi energi tenaga air dan pertumbuhan ekonomi.

Ziramba (2013) meneliti hubungan antara konsumsi listrik tenaga air dengan pertumbuhan ekonomi di tiga negara Afrika, yaitu: Mesir, Afrika Selatan, dan Aljazair selama 1980-2009. Hasil empiris menunjukkan bahwa konsumsi listrik tenaga air memiliki dampak positif pada pertumbuhan ekonomi di kedua negara (Mesir dan Afrika Selatan). Selanjutnya, mereka menemukan kausalitas dua arah antara konsumsi listrik tenaga air dan pertumbuhan ekonomi di Aljazair, padahal sudah ada dari kausalitas searah dari pertumbuhan ekonomi ke konsumsi listrik tenaga air di Afrika Selatan. Namun tidak hubungan sebab akibat yang terjalin antara kedua variabel di Mesir.

Degan menggunakan pendekatan pengujian batas ARDL, Bildirici (2014) menyelidiki hubungan antara konsumsi energi tenaga air, emisi CO2, dan ekonomi pertumbuhan di 15 negara dengan periode waktu 
yang berbeda. Hasil menunjukkan keberadaan hipotesis pertumbuhan di Austria, hipotesis konservasi di Jerman, dan hipotesis kenetralan di Inggris. Namun, hipotesis umpan balik didirikan antara konsumsi energi tenaga air dan pertumbuhan ekonomi di negara-negara lain.

Sebuah studi terbaru oleh Bildirici (2016) menemukan kehadiran kausalitas satu arah mengalir dari konsumsi energi tenaga air untuk pertumbuhan ekonomi di negara-negara OECD dengan negara-negara berpenghasilan tinggi. Studi ini juga mengkonfirmasi kausalitas satu arah berjalan dari pertumbuhan ekonomi ke konsumsi energi tenaga air di Brasil, AS, Finlandia, Meksiko, dan Turki dalam jangka pendek. Selanjutnya, mereka melaporkan kausalitas dua arah antara kedua variabel ini dalam jangka panjang.

\section{Konsumsi energi tenaga air dan emisi CO2}

Dalam dua dekade terakhir, banyak penelitian telah melaporkan bahwa konsumsi energi mengarah pada emisi $\mathrm{CO} 2$ di negara maju dan negara berkembang. Karena itu, banyak pemerintah negara dan pembuat kebijakan telah mengakui peran konsumsi energi terbarukan dalam memenuhi permintaan energi mereka tanpa adanya degradasi lingkungan. Dalam beberapa tahun terakhir, ada minat yang meningkat untuk memeriksa nexus antara konsumsi energi tenaga air dan emisi $\mathrm{CO} 2$. Misalnya, Bildirici (2014) meneliti hubungan diantara konsumsi energi tenaga air, ekonomi pertumbuhan, dan emisi $\mathrm{CO} 2$ pada 15 negara. Penulis mendokumentasikan tidak adanya hubungan sebab akibat antara konsumsi energi tenaga air dan emisi CO2 di Belgia, Islandia, dan Inggris. Namun, terdapat kausalitas satu arah dari emisi $\mathrm{CO} 2$ menuju konsumsi energi tenaga air di seluruh negara.

Lau et al. (2016) juga menganalisis hubungan antara konsumsi pembangkit listrik tenaga air, pertumbuhan ekonomi, dan emisi CO2 di Malaysia selama 1965-2010. Hasil empiris mereka terungkap bahwa konsumsi pembangkit listrik tenaga air Granger menyebabkan emisi $\mathrm{CO} 2$ dalam jangka pendek. Namun, pertumbuhan ekonomi dan Granger konsumsi listrik tenaga air menyebabkan emisi $\mathrm{CO} 2$ dalam jangka panjang.

Bildirici dan Gökmenoğlu (2017) menyelidiki hubungan antara konsumsi energi tenaga air, pertumbuhan ekonomi, dan emisi CO2 di negara-negara G7 dalam kerangka kerja multivarian, yang mencakup periode 1961-2013. Temuan mereka mengkonfirmasi bukti kausalitas searah dari konsumsi energi tenaga air hingga pertumbuhan ekonomi secara keseluruhan dan kausalitas dua arah antara dua variabel ini di beberapa negara G7. Pelajaran ini juga menemukan kausalitas searah yang berasal dari emisi $\mathrm{CO} 2$ ke konsumsi energi tenaga air dalam rezim pertama, kedua, dan ketiga, sedangkan kausalitas searah diamati dari konsumsi energi tenaga air ke emisi $\mathrm{CO} 2$ di beberapa negara G7. Selanjutnya terdapat kausalitas dua arah antara emisi $\mathrm{CO} 2$ dan pertumbuhan ekonomi dalam seluruh rezim.

\section{METODE PENELITIAN}

Penelitian ini menggunakan pendekatan kuantitatif dengan jenis penelitian kausal dan menggunakan data sekunder. Penelitian ini bertujuan untuk mencari kemungkinan terjadinya hubungan sebab dan akibat antar variabel. Penelitian ini menggunakan data sekunder dengan tahun periode 1981 hingga 2017. Data diperoleh dari IEA dan World Bank. Dengan sampel yang digunakan negara Indonesia.

Periode yang digunakan berjumlah 37 tahun, mulai dari tahun 1981 hingga 2017 dalam penelitian ini menggunakan data-data terbaru diharapkan bisa menjelaskan fenomena di lapangan dengan lebih baik. Jangka waktu 37 tahun dipilih bertujuan untuk mencakup lebih banyak data yang akan diteliti sehingga lebih relevan. Karena dalam periode tersebut yakni tahun 2000-an beberapa negara di dunia sedang gencar-gencarnya dalam meningkatkan perekonomian salah satunya dengan naiknya proses produksi disektor industri. Hal tersebut mengakibatkan emisi $\mathrm{CO} 2$ naik pada setiap tahunya, karenanya kesadaran pemerintah dan masyarat dunia terhadap kualitas lingkungan jauh lebih besar. 
Metode penelitian yang digunakan dalam penelitian ini adalah analisis restricted vector autoregressive (VAR). Metode ini digunakan untuk menganalisis hubungan pengaruh atau kausalitas antar variabel, baik terdapat kausallitas 2 arah, kausalitas satu arah, maupun tidak ada kausalitas. Dengan menggunakan data tahunan (time series) dari tahun 1981 sampai 2017.

Dalam model VAR, null-hypothesis yang dirumuskan adalah variabel $\mathrm{x}$ tidak mempengaruhi y dan hipotesis alternatifnya adalah variabel $\mathrm{x}$ dapat mempengaruhi $\mathrm{y}$. Analisis VAR merupakan model VAR yang setiap variabel penelitiannya tidak dapat terus saling mempengaruhi satu sama lain terhadap seluruh variabel, melainkan ada batasan hubungan pengaruh (restriksi). Restriksi ini ditentukan berdasarkan teori-teori bersangkutan yang ada.

Sebagai tujuan dari penelitian ini adalah untuk menganalisis kointegrasi, kausalitas Granger dan dinamika keterkaitan di antara variabel-variabel yang menarik, kami tentukan vektor autoregresif berikut (VAR) sistem untuk menemukan hubungan di antaranya:

$\mathrm{GDP}_{\mathrm{t}}=\beta_{0}+\beta_{1} \mathrm{HDR}_{\mathrm{t}-1}+\beta_{2} \mathrm{CO}_{\mathrm{t}-1}+\mathrm{e}_{\mathrm{t}}$

Di mana $\mathrm{CO} 2$ adalah Emisi karbon dioksida; HDR adalah konsumsi hydroelectricity; GDP adalah Pendapatan Domestik Bruto dan $\mathrm{t}$ adalah periode tahun.

Hubungan pengaruh yang akan diuji adalah konsumsi hydroelectricity, pertumbuhan ekonomi dan emisi CO2. Sehingga dalam proses analisis ini, jumlah variabel yang diteliti adalah sebanyak 3 variabel dengan menggunakan lag optimumnya.

Dalam melalukan proses analisis menggunakan model VAR, terdapat beberapa tahap pengujian yang harus dilakukan. Tahap-tahap pengujian tersebut antara lain sebagai berikut:

\section{Uji Unit Root}

Sebelum melakukan analisis hubungan pengaruh, perlu dipastikan terlebih dahulu apakah data dari variabel-variabel yang digunakan sudah stationer atau belum. Jika belum perlu dianalisis lebih lanjut lagi sampai datanya stationer. Stasioneritas data merupakan syarat awal sebelum melakukan analisis Vector
Autoregressive (VAR) ataupun tes hubungan pengaruh, karena jika datanya tidak stasioner bisa mengakibatkan fenomena kesimpulan yang salah. Untuk mengetahui hal tersebut, dapat digunakan uji unit root yang merupakan salah satu metode dalam menganalisis data time series. Terdapat banyak jenis tes unit root dengan metodenya yang berbeda-beda dan dalam penelitian ini jenis tes yang digunakan adalah augmented Dickey-Fuller (ADF), Phillips-Perron (PP) dan tes Kwiatkowskie-Phillipse-Schmidte-Shin (KPSS). Tipe tes yang digunakan merupakan analisis khusus data tren time series. Pada penggunaanya dalam pengujian VAR, hasil uji unit root yang digunakan harus konsisten, itu artinya hanya hasil uji dari salah satu jenis tes saja yang digunakan. Penentuan jenis tes yang paling efektif digunakan nantinya tergantung dari hasil stasioneritas yang paling baik. Oleh karena itu, terlebih dahulu dilakukan ketiga metode uji unit root tersebut.

\section{Penentuan Lag Optimal}

Ketika melakukan regresi data time series menggunakan metode VAR dan kointegrasi, biasanya penting untuk memasukkan nilai lag optimal. Dalam menentukan berapa besar lag yang optimal untuk digunakan tersebut, terdapat beberapa kriteria seleksi yang dapat diterapkan. Tiga kriteria yang paling populer adalah Akaike Information Criterion (AIC), Hannan-Quinn (HQ) dan Schwarz' Information Criterion (SIC). Gabungan ketiga metode kriteria penentuan lag optimal tersebut merupakan cara penentuan lag optimal yang digunakan dalam penelitian ini.

\section{Analisis Impulse Response Function}

Secara umum, impulse response merupakan reaksi suatu sistem dinamik dalam merespon berbagai perubahan eksternal. Lebih lanjut, impulse response menjelaskan reaksi shock sebuah sistem terhadap suatu fungsi waktu. Sehingga impulse response dapat didefinisikan sebagai suatu model yang menganalisis reaksi pengaruh oleh shock suatu variabel terhadap variabel lain yang akan terjadi di dalam periode waktu data penelitian. Reaksi pengaruh tersebut dapat berupa pengaruh positif maupun negatif, tergantung pada teori yang 
bersangkutan. Besar shock suatu variabel terhadap respon dari variabel yang dipengaruhi adalah satu dan dua dari besar standar deviasi. Ini ditujukan untuk menentukan apakah sebuah respon pada horizon tertentu significantly different from zero atau tidak.

\section{Uji Kausalitas}

Uji ini dilakukan untuk mengetahui signifikansi pengaruh atau kausalitas antar variabel penelitian yang telah ditentukan. Pengaruh yang akan diuji adalah pengaruh dari masing-masing variabel yaitu Hydroelectricity, Pertumbuhan Ekonomi, dan emisi CO2.

\section{HASIL DAN PEMBAHASAN}

\section{Unit Root Test}

Prosedur pengujian dalam penelitian ini yang pertama yaitu uji unit root pada level dan $1 s t$ difference yang dilakukan untuk menentukan apakah masing-masing variabel stasioner atau non-stasioner. Uji unit root menggunakan Augmented Dickey Fuller (ADF) tes yang dikembangkan oleh Dickey dan Fuller (1979). Tes Augmented Dickey-Fuller digunakan untuk menentukan tingkat atau derajat integrasi variabel dan juga untuk mengoreksi urutan serial korelasi yang lebih tinggi dengan menambahkan dari segi perbedaan lag. Tabel berikut akan menunjukkan hasil uji unit root untuk setiap variabel :

1. Variabel GDP

Berdasarkan hasil pengujian unit root test, variabel GDP tidak stasioner pada tingkat level akan tetapi setelah diturunkan pada tingkat $1^{\text {st }}$ difference menjadi stasioner karena nilai Prob $<0.05$. Oleh karena itu, variabel GDP stasioner pada tingkat pertama.

Tabel 1. Pengujian Unit Root Test Variabel GDP

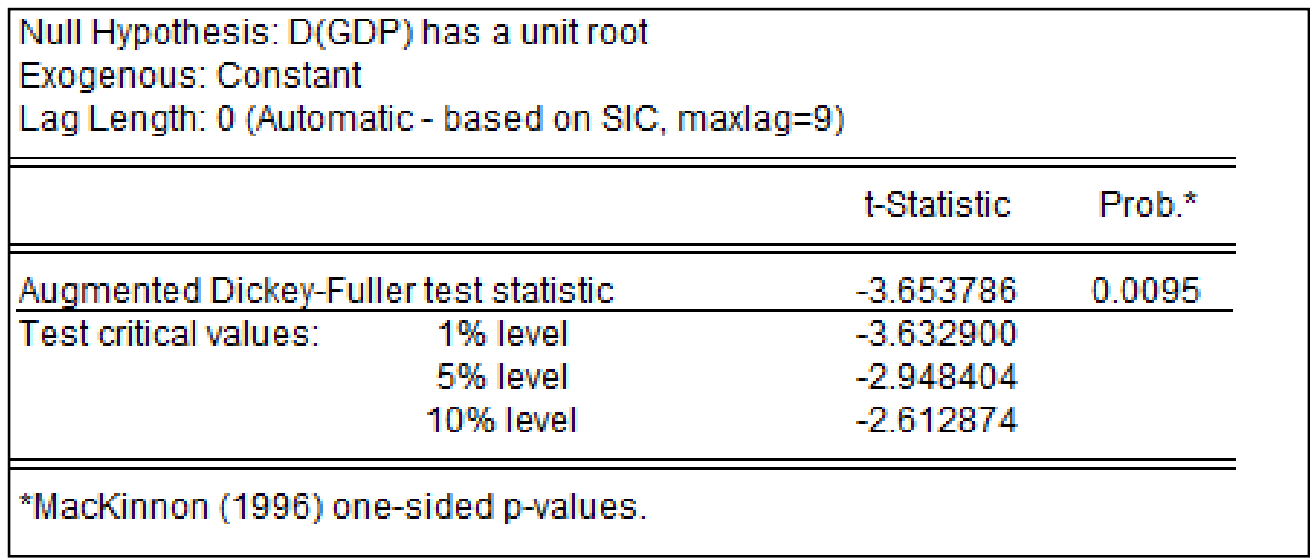

Variabel Hydroelectricity

difference menjadi stasioner karena nilai

Berdasarkan hasil pengujian unit Prob <0.05. Oleh karena itu, variabel root test, variabel hydroelectricity tidak hydroelectricity stasioner pada tingkat stasioner pada tingkat level akan tetapi pertama.

setelah diturunkan pada tingkat $1^{\text {st }}$ 
Tabel 2. Pengujian Unit Root Test Variabel Hydroelectricity

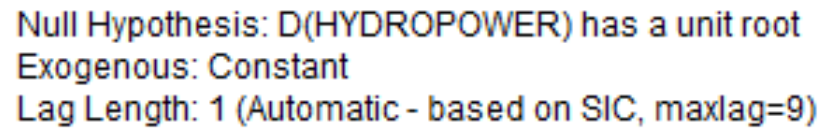

\begin{tabular}{lrrr}
\hline \hline & t-Statistic & Prob. $^{*}$ \\
\hline \hline \multicolumn{2}{l}{ Augmented Dickey-Fuller test statistic } & -9.071038 & 0.0000 \\
\hline \multicolumn{2}{l}{ Test critical values: $1 \%$ level } & -3.639407 & \\
& $5 \%$ level & -2.951125 & \\
& $10 \%$ level & -2.614300 & \\
\hline \hline
\end{tabular}

*MacKinnon (1996) one-sided p-values.

Variabel CO2 (Karbondioksida)

Berdasarkan hasil pengujian unit root test, variabel CO2 tidak stasioner pada tingkat level akan tetapi setelah diturunkan pada tingkat $1^{\text {st }}$ difference menjadi stasioner karena nilai Prob $<0.05$. Oleh karena itu, variabel $\mathrm{CO} 2$ stasioner pada tingkat pertama.

Tabel 3. Pengujian Unit Root Test Variabel CO2

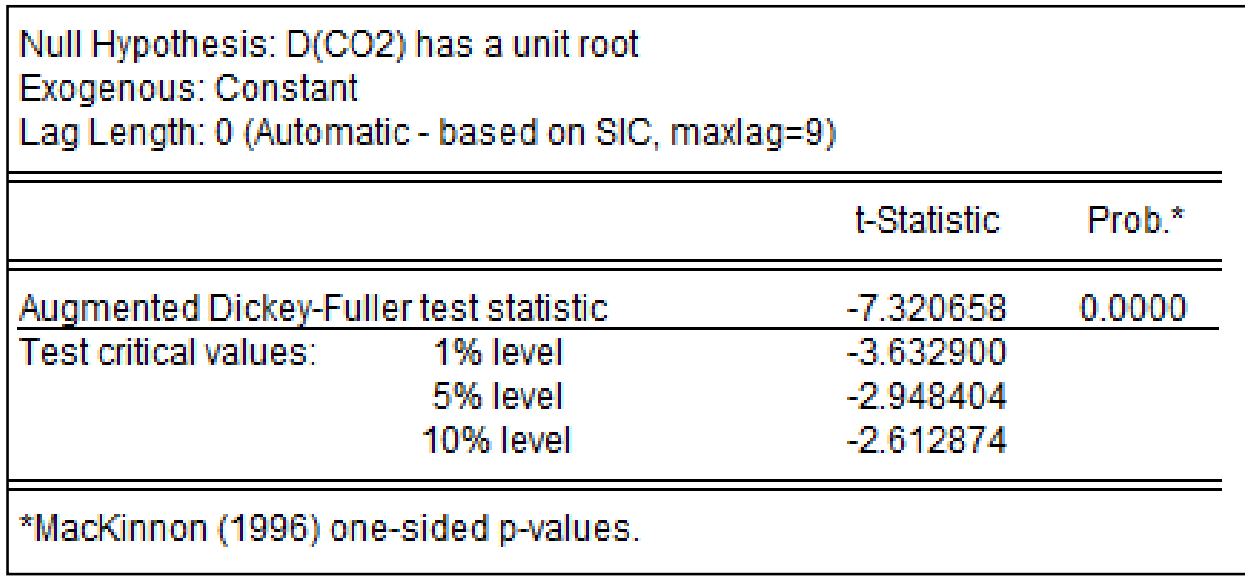


Dari ketiga tabel di atas, dapat ditarik kesimpulan bahwa variabel GDP, Hydroelectricity, dan $\mathrm{CO} 2$ tidak stasioner pada tingkat level. Namun, setelah diturunkan pada $1 s t$ difference semua variabel stationer. Oleh karena itu, semua variabel tidak stationer pada tingkat level dan terintegrasi pada tingkat pertama.

\section{Uji Kointegrasi}

Setelah menetapkan bahwa variabel GDP, Konsumsi Hydroelectricity dan Emisi Karbon dioksida (CO2) stasioner pada tingkat pertama, selanjutnya adalah menguji apakah terdapat hubungan jangka panjang di antara mereka.
Pengujian kointegrasi dimaksud untuk mengetahui hubungan dalam jangka panjang masing-masing variabel. Syarat dalam estimasi VAR, yaitu ada hubungan kointegrasi di dalamnya. Apabila tidak terdapat hubungan kointegrasi, maka estimasi VAR batal digunakan, melainkan harus menggunakan model VECM. Dalam penelitian ini, pengujian kointegrasi digunakan metode Johansen's Cointegration Test yang tersedia dalam software eviews dengan critical value 0,05 . Hasil uji kointegrasi ditunjukkan oleh tabel 4:

Tabel 4. Uji Kointegrasi Johansen's Cointegration Test

\begin{tabular}{lcccc}
\multicolumn{6}{l}{ Unrestricted Cointegration Rank Test (Maximum Eigenvalue) } \\
\hline \hline $\begin{array}{c}\text { Hypothesized } \\
\text { No. of CE(s) }\end{array}$ & Eigenvalue & $\begin{array}{c}\text { Max-Eigen } \\
\text { Statistic }\end{array}$ & $\begin{array}{c}0.05 \\
\text { Critical Value }\end{array}$ & Prob. $^{* \star}$ \\
\hline \hline None & 0.328869 & 13.95766 & 21.13162 & 0.3685 \\
At most 1 & 0.171587 & 6.588528 & 14.26460 & 0.5389 \\
At most 2 * & 0.132878 & 4.990164 & 3.841466 & 0.0255
\end{tabular}

Dari tabel diatas, dapat dilihat bahwa nilai probabilitas none 0.36 lebih besar dari nilai probabilitas 0.05 sehingga penelitian ini tetap menggunakan estimasi VAR. Oleh karena itu dalam variabel GDP, hydroelectricity dan $\mathrm{CO} 2$ tidak terdapat hubungan.

\section{Impulse Respond}

1. GDP

- Pada periode pertama, variabel GDP dapat menjelaskan dirinya sendiri sebesar $100 \%$.

- Pada periode kedua, variabel GDP dapat menjelaskan dirinya sebesar $98.57 \%$, sedangkan sisanya dijelaskan oleh variabel hydroelectricity sebesar $1.32 \%$ dan variabel $\mathrm{CO} 2$ sebesar $0.10 \%$.

- Pada periode ketiga, variabel GDP dapat menjelaskan dirinya sebesar 99.05\%, sedangkan sisanya dijelaskan variabel hydroelectricity sebesar $0.87 \quad \%$ dan variabel CO2 sebesar $0.07 \%$.

- Pada periode keempat, variabel GDP dapat menjelaskan dirinya sebesar $98.83 \%$, sedangkan sisanya dijelaskan variabel hydroelectricity sebesar $0.9 \%$ dan variabel $\mathrm{CO} 2$ sebesar $0.26 \%$. 
- Pada periode kelima, variabel GDP dapat menjelaskan dirinya sebesar $98.46 \%$, sedangkan sisanya dijelaskan variabel hydroelectricity sebesar $0.96 \%$ dan variabel $\mathrm{CO} 2$ sebesar $0.57 \%$.

- Pada periode keenam, variabel GDP dapat menjelaskan dirinya sebesar 97.99\%, sedangkan sisanya dijelaskan variabel hydroelectricity sebesar $0.97 \%$ dan variabel $\mathrm{CO} 2$ sebesar $1.02 \%$.

- Pada periode ketujuh, variabel GDP dapat menjelaskan dirinya sebesar 97.44\%, sedangkan sisanya dijelaskan variabel hydroelectricity sebesar $0.95 \%$ dan variabel $\mathrm{CO} 2$ sebesar $1.60 \%$.

- Pada periode kedelapan, variabel GDP dapat menjelaskan dirinya sebesar $96.8 \%$, sedangkan sisanya dijelaskan variabel hydroelectricity sebesar $0.89 \%$ dan variabel $\mathrm{CO} 2$ sebesar $2.3 \%$.

- Pada periode kesembilan, variabel GDP dapat menjelaskan dirinya sebesar $96.06 \%$, sedangkan sisanya dijelaskan dijelaskan variabel hydroelectricity sebesar $0.85 \%$ dan variabel CO2 sebesar 3.08\%.

- Pada periode kesepuluh, variabel GDP dapat menjelaskan dirinya sebesar $95.19 \%$, sedangkan sisanya dijelaskan variabel hydroelectricity sebesar $0.86 \%$ dan variabel $\mathrm{CO} 2$ sebesar 3.94\%.
Tabel 5 Variance Decomposition Variabel GDP

\begin{tabular}{|c|c|c|c|c|}
\hline \multicolumn{5}{|c|}{ Variance Decomposition of GDP: } \\
\hline Period & S.E. & GDP & HYDROPO... & $\mathrm{CO} 2$ \\
\hline 1 & 46596.34 & 100.0000 & 0.000000 & 0.000000 \\
\hline 2 & 80632.27 & 98.57345 & 1.321671 & 0.104879 \\
\hline 3 & 99344.14 & 99.05008 & 0.873400 & 0.076522 \\
\hline 4 & 113063.1 & 98.83269 & 0.905968 & 0.261340 \\
\hline 5 & 123959.8 & 98.46442 & 0.960194 & 0.575387 \\
\hline 6 & 132315.1 & 97.99698 & 0.976998 & 1.026020 \\
\hline 7 & 138699.6 & 97.44184 & 0.950020 & 1.608135 \\
\hline 8 & 143676.3 & 96.80255 & 0.894298 & 2.303150 \\
\hline 9 & 147671.2 & 96.06033 & 0.850956 & 3.088715 \\
\hline 10 & 151014.0 & 95.19227 & 0.862677 & 3.945054 \\
\hline
\end{tabular}

2. Hydroelectricity

Tabel 6 Variance Decomposition Variabel Hydroelectricity

\begin{tabular}{|c|c|c|c|c|}
\hline \multicolumn{5}{|c|}{ Variance Decomposition of HYDROPOWER: } \\
\hline Period & S.E. & GDP & HYDROPO ... & $\mathrm{CO} 2$ \\
\hline 1 & 0.393466 & 15.26049 & 84.73951 & 0.000000 \\
\hline 2 & 0.411089 & 16.27804 & 83.68807 & 0.033889 \\
\hline 3 & 0.418488 & 16.09753 & 82.91241 & 0.990063 \\
\hline 4 & 0.426357 & 16.04091 & 82.79493 & 1.164157 \\
\hline 5 & 0.433259 & 16.48408 & 82.07056 & 1.445360 \\
\hline 6 & 0.439246 & 17.32425 & 80.90196 & 1.773792 \\
\hline 7 & 0.445667 & 18.50995 & 79.32121 & 2.168840 \\
\hline 8 & 0.452384 & 19.86156 & 77.53663 & 2.601813 \\
\hline 9 & 0.459229 & 21.22324 & 75.68686 & 3.089907 \\
\hline 10 & 0.466139 & 22.52178 & 73.85158 & 3.626633 \\
\hline
\end{tabular}

- Pada periode pertama, variabel hydroelectricity dapat menjelaskan dirinya sebesar $84.73 \%$, sedangkan sisanya dijelaskan oleh variabel GDP sebesar $15.26 \%$.

- Pada periode kedua, variabel hydroelectricity dapat menjelaskan dirinya sebesar $83.68 \%$, sedangkan sisanya dijelaskan oleh variabel DGP sebesar $16.27 \%$ dan variabel CO2 sebesar $0.03 \%$

- Pada periode ketiga, variabel hydroelectricity dapat menjelaskan dirinya sebesar $82.91 \%$, sedangkan sisanya dijelaskan variabel GDP sebesar $016.09 \%$ dan variabel $\mathrm{CO} 2$ sebesar $0.99 \%$

- Pada periode keempat, variabel hydroelectricity dapat menjelaskan 
dirinya sebesar $82.79 \%$, sedangkan sisanya dijelaskan variabel GDP sebesar $16.04 \%$ dan variabel $\mathrm{CO} 2$ sebesar $1.16 \%$

- Pada periode kelima, variabel hydroelectricity dapat menjelaskan dirinya sebesar $82.07 \%$, sedangkan sisanya dijelaskan variabel GDP sebesar $16.48 \%$ dan variabel $\mathrm{CO} 2$ sebesar $1.44 \%$.

- Pada periode keenam, variabel hydroelectricity dapat menjelaskan dirinya sebesar $80.9 \%$, sedangkan sisanya dijelaskan variabel GDP sebesar $17.32 \%$ dan variabel $\mathrm{CO} 2$ sebesar $1.77 \%$.

- Pada periode ketujuh, variabel hydroelectricity dapat menjelaskan dirinya sebesar $79.32 \%$, sedangkan sisanya dijelaskan variabel GDP sebesar $18.5 \%$ dan variabel $\mathrm{CO} 2$ sebesar $2.16 \%$.

- Pada periode kedelapan, variabel hydroelectricity dapat menjelaskan dirinya sebesar $77.53 \%$, sedangkan sisanya dijelaskan variabel GDP sebesar $19.86 \%$ dan variabel $\mathrm{CO} 2$ sebesar $2.6 \%$.

- Pada periode kesembilan, variabel hydroelectricity dapat menjelaskan dirinya sebesar $75.68 \%$, sedangkan sisanya dijelaskan variabel GDP sebesar $21.22 \%$ dan variabel $\mathrm{CO} 2$ sebesar 3.08\%.

- Pada periode kesepuluh, variabel hydroelectricity dapat menjelaskan dirinya sebesar $73.85 \%$, sedangkan sisanya dijelaskan variabel GDP sebesar $22.52 \%$ dan variabel $\mathrm{CO} 2$

sebesar 3.62\%.

3. $\mathrm{CO} 2$

\section{Tabel 7 Variance Decomposition}

Variabel $\mathrm{CO} 2$

\begin{tabular}{|c|c|c|c|c|}
\hline \multicolumn{5}{|c|}{ Variance Decomposition of $\mathrm{CO} 2$ : } \\
\hline Period & S.E. & GDP & HYDROPO... & $\mathrm{CO} 2$ \\
\hline 1 & 10.08759 & 7.734207 & 3.726356 & 88.53944 \\
\hline 2 & 12.07069 & 7.615194 & 10.83720 & 81.54761 \\
\hline 3 & 14.30620 & 6.075032 & 19.32893 & 74.59603 \\
\hline 4 & 16.13382 & 5.076746 & 24.55802 & 70.36523 \\
\hline 5 & 17.95588 & 4.764314 & 28.89119 & 66.34449 \\
\hline 6 & 19.70908 & 5.147073 & 32.31508 & 62.53785 \\
\hline 7 & 21.41256 & 6.075385 & 34.64325 & 59.28137 \\
\hline 8 & 23.08203 & 7.500810 & 36.05588 & 56.44331 \\
\hline 9 & 24.74081 & 9.323011 & 36.74243 & 53.93456 \\
\hline 10 & 26.39997 & 11.41506 & 36.87737 & 51.70757 \\
\hline & & & NER CO2 & \\
\hline
\end{tabular}

- Pada periode pertama, variabel CO2 dapat menjelaskan dirinya sendiri sebesar $88.53 \%$, sedangkan sisanya dijelaskan variabel GDP sebesar $7.73 \%$ dan variabel hydroelectricity sebesar $3.72 \%$.

- Pada periode kedua, variabel CO2 dapat menjelaskan dirinya sebesar $81.54 \%$, sedangkan sisanya dijelaskan oleh variabel GDP sebesar $7.61 \%$ dan variabel hydroelectricity sebesar $10.83 \%$.

- Pada periode ketiga, variabel CO2 dapat menjelaskan dirinya sebesar $74.59 \%$, sedangkan sisanya dijelaskan variabel GDP sebesar $6.07 \%$ dan variabel hydroelectricity sebesar $19.32 \%$.

- Pada periode keempat, variabel CO2 dapat menjelaskan dirinya sebesar $70.36 \%$, sedangkan sisanya dijelaskan variabel GDP sebesar $5.07 \%$ dan variabel hydroelectricity sebesar $24.55 \%$. 
- Pada periode kelima, variabel CO2 dapat menjelaskan dirinya sebesar $66.34 \%$, sedangkan sisanya dijelaskan variabel GDP sebesar $4.76 \%$ dan variabel hydroelectricity sebesar $28.89 \%$.

- Pada periode keenam, variabel CO2 dapat menjelaskan dirinya sebesar $62.53 \%$, sedangkan sisanya dijelaskan variabel GDP sebesar $5.14 \%$ dan variabel hydroelectricity sebesar $32.31 \%$.

- Pada periode ketujuh, variabel $\mathrm{CO} 2$ dapat menjelaskan dirinya sebesar $59.28 \%$, sedangkan sisanya dijelaskan variabel GDP sebesar $6.07 \%$ dan variabel hydroelectricity sebesar $34.64 \%$.

- Pada periode kedelapan, variabel $\mathrm{CO} 2$ dapat menjelaskan dirinya sebesar $56.44 \%$, sedangkan sisanya dijelaskan variabel GDP sebesar $7.5 \%$ dan variabel hydroelectricity sebesar $36.05 \%$.
- Pada periode kesembilan, variabel CO2 dapat menjelaskan dirinya sebesar $53.93 \%$, sedangkan sisanya dijelaskan variabel GDP sebesar $9.32 \%$ dan variabel hydroelectricity sebesar $36.74 \%$.

- Pada periode kesepuluh, variabel $\mathrm{CO} 2$ dapat menjelaskan dirinya sebesar $51.7 \%$, sedangkan sisanya dijelaskan variabel GDP sebesar $11.41 \%$ dan variabel hydroelectricity sebesar $36.87 \%$.

\section{Lag Maximum}

Pengujian lag maksimum untuk analisis VAR ditentukan melalui uji gabungan ketiga metode kriteria penentuan lag maksimum, yaitu Akaike Information Criterion (AIC), Hannan Quinn dan Schwarz' Information Criterion (SIC). Besar lag maksimum yang efektif untuk dipilih sebagai input dalam analisis VAR, dapat diketahui melalui hasil pengujian yang terdapat pada information criteria. Tabel 8 adalah hasil penentuan lag maksimum :

Tabel 8 Hasil Penentuan Lag Maksimum

\begin{tabular}{|ccccccc}
\hline \hline Lag & LogL & LR & FPE & AIC & SC & HQ \\
\hline \hline 0 & -701.8762 & NA & $6.24 \mathrm{e}+13$ & 40.27864 & 40.41195 & 40.32466 \\
1 & -568.4181 & 236.4115 & $5.11 \mathrm{e}^{*}+10$ & 33.16675 & $33.70001^{*}$ & 33.35083 \\
2 & -556.7193 & $18.71797^{*}$ & $4.43 e^{*}+10^{*}$ & $33.01253^{*}$ & 33.94574 & $33.33468^{*}$ \\
\hline \hline
\end{tabular}

Berdasarkan hasil penentuan lag optimal menurut ketiga metode tersebut, lag yang paling optimal dan akan efektif untuk digunakan dalam analisis VAR adalah sebanyak 2 lags atau $p=2$. 


\section{Uji Kausalitas}

Uji kausalitas dilakukan untuk mengetahui apakah suatu variabel endogen dapat diperlakukan sebagai variabel eksogen. Uji kausalitas dapat dilakukan dengan berbagai metode diantaranya metode Granger's Causality dan Error Correction Model Causality. Pada penelitian ini, digunakan metode Granger's Causality. Granger's Causality untuk menguji adanya hubungan kausalitas antara dua variabel.

Dari dua pengujian data sebelumnya, semua variabel telah memenuhi persyaratan stasioneritas data uji ADF dimana, stasioner pada tingkat first difference. Oleh karena semua variabel data sudah stasioner pada tingkat first difference, dapat dilakukan langkah selanjutnya yaitu dengan melakukan uji kointegrasi. Setelah didapati hasil bahwa nilai probabilitas $>0.05$ maka model yang digunakan dalam estimasi adalah Model VAR. Terakhir, langkah yang dilakukan adalah melakukan uji kausalitas. Setelah dilakukan uji ini didapatkan hasil sebagai berikut:

Tabel 9. Uji Kausalitas

\begin{tabular}{llccc}
\hline Sample: 19812017 \\
Lags: 2 \\
\hline \hline Null Hypothesis: & Obs & F-Statistic & Prob. \\
\hline \hline HYDROPOWER does not Granger Cause GDP & \multirow{2}{*}{35} & 2.79186 & 0.0773 \\
GDP does not Granger Cause HYDROPOWER & & 4.07833 & 0.0271 \\
\hline \hline CO2 does not Granger Cause GDP & \multirow{2}{*}{35} & 3.32140 & 0.0498 \\
GDP does not Granger Cause CO2 & & 1.41022 & 0.2598 \\
\hline \hline CO2 does not Granger Cause HYDROPOWER & \multirow{2}{*}{35} & 4.33347 & 0.0222 \\
HYDROPOWER does not Granger Cause CO2 & & 7.31494 & 0.0026 \\
\hline
\end{tabular}

Berdasarkan hasil uji kausalitas diatas dapat dijelaskan bahwa variabel yang memiliki hubungan kausalitas granger ialah variabel dengan nilai probabilitas lebih kecil dari $\alpha=0,05$. Penjelasannya sebagai berikut :

a. Variabel Hydroelectricity tidak ada kausalitas dengan variabel GDP karena nilai probabilitas $0,0773>0,05$ dan untuk variabel GDP ada kausalitas satu arah terhadap variabel Hydroelectricity karena nilai probabilitas $0,0271<0,05$. Dapat disimpulkan bahwa terjadi kausalitas searah antara variabel GDP dan Hydroelectricity, yaitu variabel Hydroelectricity yang secara statistik berkausalitas terhadap variabel GDP, namun tidak berlaku sebaliknya. Hal ini sejalan dengan penelitian oleh Alfisyahri, et al (2020), dengan hasil penelitian variabel GDP memiliki kausalitas satu arah terhadap variabel Hydroelectricity pada negara China, India, Turki, Kanada, dan Prancis.

b. Variabel $\mathrm{CO} 2$ memiliki kausalitas terhadap variabel GDP karena nilai probabilitas $0,0498<0,05$ dan untuk variabel GDP tidak memiliki kausalitas terhadap variabel $\mathrm{CO} 2$ karena nilai probabilitas $0,2598>0,05$. Dapat disimpulkan bahwa variabel $\mathrm{CO} 2$ menjadi kausalitas dari variabel GDP. Dengan didukung penelitian oleh Karimi, et al (2020) dengan variabel CO2 memiliki kausalitas satu arah terhadap GDP pada negara China, India, dan Rusia.

c. Variabel $\mathrm{CO} 2$ ada kausalitas terhadap variabel Hydroelectricity karena nilai probabilitas $0,0222<0,05$ dan variabel 
Hydroelectricity memiliki kausalitas terhadap $\mathrm{CO} 2$ karena nilai probabilitas $0,0026<0,05$. Dapat disimpulkan bahwa terjadi kausalitas dua arah antar variabel Hydroelectricity dan $\mathrm{CO} 2$ yang bisa diartikan variabel tersebut memiliki timbal balik antar keduanya. Hal ini di dukung penelitian oleh Karimi,et al (2020), yang hasilnya adanya kausalitas dua arah antara Hydroelectricity terhadap CO2 hanya pada Negara Uni Eropa yang mempengaruhi dalam jangka pendek.

\section{SIMPULAN}

Menurut hasil analisis di atas dapat disimpulkan bahwa konsumsi energi hydropower terdapat kausalitas dua arah terhadap gross domestic product pada Negara Indonesia. Munculnya energi terbarukan yaitu energy hydropower dapat mengakibatkan gross domestic product meningkat. Begitupula dengan kondisi gross domestic product yang semakin tinggi pada suatu negara mendorong negara tersebut akan memanfaatkan energi terbarukan sebagai sumber energi di negaranya.

GDP (gross domestic product) terdapat kausalitas satu arah terhadap Emisi karbon dioksida. Yang berarti bahwa terdapat pengaruh antara emisi karbon dioksida terhadap gross domestic product. Sedangkan gross domestic product terhadap emisi karbon dioksida tidak terdapat pengaruh.

Emisi karbon dioksida terdapat kausalitas dua arah terhadap konsumsi energi hydropower. Berarti bahwa semakin tinggi emisi karbon dioksida pada suatu negara maka konsumsi energi terbarukan yaitu energi hydropower semakin meningkat. Dengan diterapkannya energy hydropower pada suatu negara maka emisi karbon dioksidanya akan semakin menurun karena energi tersebut ramah lingkungan.

\section{DAFTAR PUSTAKA}

Abakah EM (1993) A review of economic growth and energy consumption in a developing country; Ghana. OPEC Energy Rev 17(1):47- 61

Bildirici ME (2014) Hydroelectricity energy consumption, environmental pollution, and economic growth. J Energy Dev 40(1/2):189-208.

Bildirici M (2016) The relationship between hydroelectricity energy consumption and economic growth. Proc Econo Finance 38:264-270.

Bildirici, M. E., \& Gökmenoğlu, S. M. (2017). Environmental pollution, hydroelectricity energy consumption and economic growth: Evidence from G7 countries. Renewable and Sustainable Energy Reviews, 75(October), 6885 .

https://doi.org/10.1016/j.rser.2016.10.052

Nuriah Alfisyahri, Syafruddin KArimi, E. R. (2020). Hubungan Kausalitas Konsumsi Energi Hydroelectricity, Emisi Karbon Dioksida dan Pertumbuhan Ekonomi pada Negaranegara G20. Jurnal Ilmiah MEA (Manajemen, Ekonomi, Dan Akuntansi), 4(1), 114-127.

Okafor HO (2012) Testing the relationship between energy consumption and economic growth: evidence from Nigeria and South Africa. J Econ Sustain Dev 3(11):111-124

Zakiah Husna, I. (2019). Pengaruh Konsumsi Energi dan Rezim Terhadap Pertumbuhan Ekonomi. Jurnal Kajian Ekonomi Dan Pembangunan, 1(2), 401-408. https://doi.org/10.1017/CBO97811074153 24.004 .

Ziramba E (2013) Hydroelectricity consumption and economic growth nexus: time series experience of three African countries. Eur Sci J 9(1):85-96

Basyiran, T. B. (2016). Konsumsi Energi Listrik, Pertumbuhan Ekonomi Dan Penduduk Terhadap Emisi Gas Rumah Kaca Pembangkit Listrik Di Indonesia. 1-54.

Eduardo Heyko, Z. H. (2016). Strategi Pemanfaatan Energi Terbarukan Dalam Rangka Kemandirian Energi Daerah Provinsi Kalimantan Timur. Jurnal Ekonomi Keuangan dan Manajemen, 1-28.

Mallesh Ummalla, A. S. (2018). The Impact Of Hydropower Energy Consumption On Economic Growth And CO2 Emissions in China. Environmental Science and Pollution Research, 35725-35737. 
Nani D. I.S, Fika R., Dewi P. I. P. \& Devana S. Y./ INDICATORS Journal of Economics and Business Vol 1 (2) (2019)

Serdo Nurdi Putra, A. S. (2019). Analisis Hubungan Kausalitas Pengguna Energi, Pertumbuhan Ekonomi Dan Emisi Lingkungan Di Indonesia. Jurnal Ekonomi Pembangunan, 4968. 